\title{
Critical Review on the Idea of Dystopia
}

\author{
Ruzbeh Babaee ${ }^{1}$, Hardev Kaur A/P Jujar Singh ${ }^{1}$, Zhang Zhicheng ${ }^{1} \&$ Zhang Haiqing ${ }^{1}$ \\ 1. Faculty of Modern Languages and Communication, Universiti Putra Malaysia, Serdang, Malaysia \\ Correspondence: Ruzbeh Babaee, Faculty of Modern Languages and Communication, Universiti Putra Malaysia, \\ Serdang, Malaysia. Tel: 60-142-340-937. E-mail: ruzbeh_babaei@upm.edu.my
}

Received: May 8, 2015 Accepted: June 18, 2015 Online Published: June 26, 2015

doi:10.5539/res.v7n11p64 URL: http://dx.doi.org/10.5539/res.v7n11p64

\begin{abstract}
The purpose of this review is firstly to show the formation of dystopia that finds its roots in utopia. Then, the foundation of dystopian fiction from the perspectives of such critics as Chad Walsh, Tom Moylan, Mark R. Hillegas, and Erika Gottlieb, among some others, is investigated. Finally, we briefly reveal the standing of Aldous Huxley, Kurt Vonnegut, and Don DeLillo, among many other dystopian writers, in depiction of dystopian societies. This study also attempts to explain how works of these three writers were revolutionary in their challenging of the new values that led to the degradation of human dignity.
\end{abstract}

Keywords: Dystopia, Utopia, Technology, Huxley, Vonnegut, DeLillo

\section{From Utopia to Dystopia}

For the present study, it is important to show that the dystopian literature emerging in the twentieth century was rooted in a utopian vision that invests in our imagination that seeks to create an ideal and perfect world. (Note 1) Utopia as an organized concept encourages everybody to investigate the norms of organization and to discover ideal systems through which human lives could be made better. It is not easy to consider all of the utopian works and thinking informing the genre today, but utopia began with the myth of Eden. The first utopian thought refers back to Plato whose Republic is considered one of the pioneering utopian works (Russell 2005). Plato, in Republic, describes a model for an ideal world; however, it was not until the 1500s, when the term utopia was coined by Sir Thomas More in his work of the same name that illustrates a fictional society on a remote island in 1516. More was the first to think of a true utopia by setting up what Fátima Vieira (2010) sees as a "tension between the affirmation of a possibility and the negation of its fulfilment" (p. 6). Although a pleasing goal, utopia has never existed. More, in his Utopia, which means 'No Place', shows that utopia is an impractical ideal world as well as a medium to satirize the writer's society. More sets his utopian world on an isolated island, but makes it contemporary with his own time. He depicts a society in which individual possession is revoked, education is for all, men and women are considered equally, and there are no limitations on religious practice. For More, according to David Harvey (2000), "Utopia is an artificially created island, which functions as an isolated, coherently organized, and largely closed space economy" (p. 160). He continues that utopia "becomes with More's initiative, a fertile means to explore and express a vast range of competing ideas about social relationships, moral orderings, political-economic systems, and the like" (p. 161). David Sisk (1997) also believes that utopian literature

Explores [the] perfectibility of human society through hypothetical advancements in technology, philosophy, and social structures, resulting in perfect or near-perfect communities located in distant lands or in the future. (p. 2)

He observes that utopian writers usually create patterns of perfect and organized societies, and present fleeing as a fancy of the imagination.

However, at the outset of the eighteenth century, many thinkers and writers recognised the impossibility of utopian thinking, and then a wave of anti-utopianism emerged in literature. Anti-utopian works reject the utopian desire as an unrealistic and impossible quest for an ideal future; however, they also feared that such claims could have devastating effects on the population. According to Peter Fitting (2010), anti-utopianism is "explicitly or implicitly a defence of the status quo" (p. 141). For instance, Jonathan Swift's Gulliver's Travels, an anti-utopian novel, supports the real world and condemns looking for a better world. According to Vieira (2010), early anti-utopian novels "denounce the irrelevance and inconsistency of utopian dreaming and the ruin of society 
[that dreaming] might entail" (p. 16).

In the Enlightenment era, humans' fate was reconsidered and "[man] discovered that reason could enable him not only to have a happy life, but also to reach human perfection" (Vieira 9). In this era, utopian writing emerged in such works as Samuel Butler's Erewhon and William Morris' News from Nowhere, and utopia was again a possibility for humanity. A time of scientific progress, the nineteenth century looked hopefully to the future. Although people were thinking of an ideal future, not everyone was optimistic about scientific developments. Again, anti-utopian thoughts appeared in the works of writers such as H. G. Wells who felt that humans were moving towards failure through these advances.

The politically and economically turbulent atmosphere of the late nineteenth century raised powerful critiques that led to deterioration in utopian thought. Harvey (2000) states that:

...[t]here is a time and place in the ceaseless human endeavor to change the world, when alternative visions, no matter how fantastic, provide the grist for shaping powerful political forces for change. I believe we are at precisely such a moment. (p. 195)

At the outset of the twentieth century, according to Scholes and Robkin (1977), "the utopian impulse was largely replaced by dystopian projections of disastrous current trends" (p. 174). These conditions paved the way for twentieth century authors such as Yvengy Zamiatin, Aldous Huxley, and George Orwell to write dystopian fiction (Hillegas 15). In "From Utopia to Nightmare", Chad Walsh (1962) argues that utopia is replaced by dystopia in a century of disillusionment. He states,

I submit that the shift from utopian to dystopian fiction is important. Quite possibly, it foreshadows one of those really massive psychological shifts that sometimes occur over a whole culture. (p. 117)

While it is easy to define utopia as an ideal world, defining dystopia under one umbrella term seems to be challenging. However, for this study, dystopia is a critical genre that makes us aware of human manipulation through technological advances in the twentieth and twenty-first centuries.

\section{Foundations of Dystopian Fiction}

In line with Tom Moylan (2003), we establish the beginning of technological dystopian fiction with M.H. Foster. Moylan, in Scraps of the Untainted Sky, considers M. H. Forster to be one of the archetypes of dystopian fiction. Forster is famous for A Room with a View and A Passage to India, but The Machine Stops (1909) (Note 2) credits him as a pioneer of dystopian literature. Moylan (2003) states, "Forster's story therefore stands as an early example of the dystopian maps of social hells that have been with us ever since" (p. 112). Moreover, Beauchamp, in his essay "Technology in the Dystopian Novel", states, "Except perhaps for Wells's When the Sleeper Awakes, The Machine Stops is probably the first modern dystopia" (p. 57).

After Forster's The Machine Stops, much more dystopian fiction emerged, among which the most well-known is Yevgeny Zamyatin's We (1924), Aldous Huxley's Brave New World (1932), and George Orwell's 1984 (1949), that are also known as the paradigm of dystopian narratives in the twentieth century. M. Keith Booker (1994a) states that these three fictions are

The great defining texts of the genre of dystopian fiction, both in [the] vividness of their engagement with real-world social and political issues, and in the scope of their critique of the societies on which they focus. (pp. 20-21)

$W e$ is recognized as the prototype of dystopia, even the motivation for Orwell to write 1984. Zamyatin's We is a criticism of the faith of humans; Huxley's Brave New World is a reaction to capitalism and bourgeois society; and Orwell's 1984 is a criticism of Stalin's totalitarianism.

Chad Walsh (1962) sees Brave New World as the most well-known example of dystopia and "the most perfect from a literary viewpoint" (92). He also sees Zamyatin's We as a text "distinguished by a high literary quality and characters who have some reality and psychological depth - literary luxuries in both utopia and dystopia" (p. 104). Moreover, Walsh considers 1984 as "the composite dystopia" (p. 107). He argues that dystopian writers are much more tolerant than their utopian counterparts:

It seems that sometimes the mildly neurotic, who know that all men move through varying and elusive shadows and that terrors lurk by every path, are tougher than the well-adjusted cheerful men who laugh at them (p. 117).

Furthermore, Mark R. Hillegas (1967) states, 
It is a truism that one of the most revealing indexes to the anxieties of our age is the great flood of works like Zamyatin's We, Huxley's Brave New World, and Orwell's Nineteen Eighty-four. (p. 3)

Hillegas' observation reflects Walsh's attitude and he also compares these novels to the technological utopias and works of Wells. Hillegas (1967) prefers the term "anti-utopia" to dystopia, as he asserts that, "this is the term most often used" (p. 3). Although Hillegas' work is informative, he directly attributes to Wells all the motifs and themes used by other dystopian writers as though they did not have any opinions of their own.

Moreover, Erika Gottlieb (2001) investigates three other popular fiction as a delegate of dystopia: Kurt Vonnegut's Player Piano (1952), a criticism of a quite mechanized and consumer world that deprecates everything concerning humanity; Ray Bradbury's Fahrenheit 451 (1953), a criticism of a society in which reading is illegal; and Margaret Atwood's The Handmaid's Tale (1986), a feminist satire of totalitarianism. Gottlieb (2001) explains,"

To a significant extent, each of these novels makes us ponder how an originally utopian promise was abused, betrayed or, ironically fulfilled so as to create tragic consequences for humanity. (p. 8) (Note 3)

However, for us, utopia is itself a deceptive promise. It is not abused or betrayed; instead it is both a deceitful and misleading promise.

Moreover, many contemporary critics have found that dystopian texts have come true about the present situation rather than about the future. Peter Firchow (1984) argues that, "most of the memorable utopian fictions of our time are largely pessimistic — not of course about the future, but really about the present" (p. 5). However, for us, dystopian novels do not have a pessimistic tone as severe as the one that Firchow states; instead they hold largely critical attitudes towards the status quo and ask for change. Essentially, it is in the essence of dystopian fiction to make the reader aware of the truth and reality of their life, a call to wake us up from the lies and unreal aspects of our life. (Note 4)

\section{Critical Review on Huxley, Vonnegut and DeLillo's Dystopian Fiction}

In the following, we review the scholarship on Huxley's Brave New World (1932) and Ape and essence (1948); Vonnegut's Player Piano (1952) and Slaughterhouse-Five (1969); and DeLillo's White Noise (1985) and Cosmopolis (2003) to contextualize our research and its original contribution to the field.

\subsection{Aldous Huxley's Speculative Dystopian Fiction}

Aldous Huxley (1894-1963) is known as one of the most significant authors of the twentieth century. His fiction has been considered influential on a generation that had their dreams ruined by two world wars. Huxley's main concern was the human lifestyle in modern society, and through literature he attempts to depict the conflict between science and the humanities. (Note 5)

Among the vast body of criticism on Huxley's fiction, Robert S. Baker (1995) claims that Huxley's novels reveal the real nature of science and technology. Furthermore, he explains that Huxley's full range of novels disclose a sustained criticism of the false claims made by science and technology. He observes the exploitation of international cartels, gratuitous sadism, the rule of technocratic experts, and the threatening forms of power in Huxley's fiction.

Among Huxley's body of literature, Brave New World is his best-known work. Peter Firchow (1984) follows the pattern of utopian writers that extends from Plato to Orwell. Written in the early 1930s, the era of the Great Depression with another world war threatening, Firchow explains that Brave New World presents a frightening future when a complete system of material prosperity and physical pleasures is finally achieved through technology. Now, over eighty years after its publication, Huxley's Brave New World has become more than a novel and is seen as quite relevant to the fields of genetic engineering, bioscience, computer hypertext and virtual reality. (Note 6)

Huxley wrote Brave New World when America and Europe were in economic, political, and social crisis in the aftermath of the First World War. Harold Bloom (2011) sees how "massive industrialization, coupled with severe economic depression and the rise of fascism" formed "Huxley's cautionary vision of the future" (p. 14). Bloom also observes that Brave New World "is still a vision of T.S. Eliot's The Waste Land, of a world without authentic belief and spiritual values" (p. 8)."

However, unlike Bloom, Milton Birnbaum (2006) argues that through his fiction, Huxley raises the question of how the world can attain value and meaning. He notes that while Huxley was captivated by technology, he 
continuously criticized the inability of new technologies to figure out the complicated issues of life. However, in our eyes, Birnbaum was unable to see that Huxley addresses the efficiency of new technologies in human manipulation. Additionally, Huxley is not captivated by technology; instead, he maintains a warning tone towards uncontrolled technological advances.

Michael Spindler (1995) also notes Huxley's cautionary tone in Brave New World. He criticizes the controlling nature of technology and explains the danger of conditioning humans in Brave New World. He also sees that the way in which the government controls individuals in Brave New World is like the way in which public media control people. Spindler argues that the thoughtless citizens illustrated in Brave New World display the way in which the public media foster empty dreams and illusions to control society. He concludes that in an era of domination by the mass media, particularly the supremacy of television in the American lifestyle, communities should wear critical lenses to look at the dangerous social issues raised by the intrusive power of technology."

In tune with Splinder, Ciro Alfonso Sandoval-Becerra (1991) criticizes technology and sees the replacement of humanity by technology in Brave New World. He finds Huxley to be among those thinkers who have highly affected modern views of technology. Ciro argues that the Greek concept of humanity as the measure of all things has been replaced in the modern era by technology. A constant flood of undigested information, work specialization, and the quest for power over nature has contributed to this condition.

Huxley's fiction has also raised materialistic and cultural concerns among literary critics. As Nicholas Murray (2003) notes,

...was much more than a "nightmare vision" of babies in bottles. It was ... about science and human freedom, culture and democracy, and the manipulation of the citizen by mass media and modern consumer capitalism. (p. 256)

Similarly, John Attarian (1996) claims that Huxley's dystopian insights into a thoughtless, self-indulgent and soulless world in Brave New World have been fulfilled in America today. He refers to earnestness in euthanasia, the degradation of modern art and failure of the education system as some examples of the present cultural decay. Superficial popular demands are evidence of a banal society devoted to hedonism and blinded to spirituality. Attarian considers the danger that Huxley sees in Brave New World in which common people are strongly affected by materialism.

Moreover, unlike Bloom and Firchow who see Brave New World as Huxley's warning to the future, for many critics Brave New World happens in the present era. Leon Kass (2000) declares:

Huxley's novel is, of course, science fiction. But yesterday's science fiction is rapidly becoming today's fact. Prozac is not yet Huxley's soma; cloning by nuclear transfer or splitting embryos is not exactly Bokanovski fiction; MTV and virtual-reality parlors are not quite the 'feelies'; and our current safe and consequenceless sexual practices are not universally as loveless or as empty as in the novel. But the kinships are disquieting, all the more so since our technologies of bio-psycho-engineering are still in their infancy-and it is all too clear what they might look like in their full maturity. (pp. 51-52)

Kass (2002) also states that, "creating and manipulating life in the laboratory is the gateway to a Brave New World, not only in fiction but also in fact" (p. 141). Kass (2002) warns that we have unwittingly created a Brave New World:

In Huxley's novel, everything proceeds under the direction of an omnipotent, albeit benevolent, world state. Yet the dehumanization that he depicts does not really require despotism or external control. On the contrary, precisely because the society of the future will deliver exactly what we most want - health, safety, comfort, plenty, pleasure, peace of mind and length of days - we can reach the same humanly debased condition solely by free human choice. No need for World Controllers just give us the technological imperative liberal democratic society compassionate humanitarianism, oral pluralism and free markets and we can take ourselves to a Brave New World all by ourselves-without even deliberately deciding to go. (p. 6)

Kass sees that we are moving automatically towards a brave new world. He is worried about human devaluation through the technology that indirectly affects our life.

In the preset study, we are more in line with Robert S. Baker (1990) who contends that Huxley's novel traces only the darker aspects of advancing scientific methods, such as those capable of producing a cloned or otherwise modified race of beings. If properly controlled, these techniques could also eradicate the worst of all 
diseases. The real problem for Huxley and modern society, according to Baker, is not one of genetics or medical science, but the likely exploitation of technological advances in a materialistic society.

Beside Brave New World, in his next but less critically received dystopian fiction, Ape and Essence, Huxley considers the degradation of human values in relation to technological developments, particularly the atom bomb. Keith Leslie Johnson (2009) sees Ape and Essence as an "underappreciated dystopian satire" (p. 582) and as Huxley's "secret masterpiece" (ibid.). He also considers the relationship between Darwin's theory and Huxley's Ape and Essence. He argues:

That novel, more bracingly and explicitly than any other in Huxley's oeuvre, speaks to the impasse of reception Darwin faces in the twentieth and twenty-first centuries as we increasingly contemplate (and realize) the exhilarating and horrifying implications of his thought. (p. 573)

Ape and Essence (Note 7) is usually regarded as a criticism of the nuclear age and of the militarization of technology that can lead to dehumanization. In 1947, in a letter to Anita Loos, Huxley (1969) states his thoughts about the novel, how it is

...about, among other things, a post-atomic-war society in which the chief effect of the gamma radiations had been to produce a race of men and women who don't make love all the year round, but have a brief mating season. The effect of this on politics, religion, ethics, etc. would be something very interesting and amusing to work out. (p. 534)

In Ape and Essence, Huxley uses the atomic bomb as a device to encourage readers to think about the reality of bombs and science. He asks his readers to think about the idea of dehumanization that can result from unchecked technological advances.

\subsection{Kurt Vonnegut's Autobiographical Dystopian Fiction}

Kurt Vonnegut (1922-2007) is recognized as one of the best-known and widely read American authors. Vonnegut's works reflect many aspects of his personal life that was replete with tragedies, such as imprisonment in the Second World War, divorce, the death from cancer of his first wife, his own depression, his attempt to suicide in 1984, and his house fire in 2000. (Note 8)

There is a vast body of critical work on Vonnegut's fiction. David Simmons (2009) edited a collection of essays on Kurt Vonnegut in New Critical Essays on Kurt Vonnegut in which Todd Davis sees Vonnegut's writing and speaking persona as being as close as possible to the real thing (p. 3). Moreover, in the same collection, Paul Thomas argues that Vonnegut offers the contemporary reader universal considerations of the complexities inherent in the human condition (his persistent wrestling with free will, for example), and his works create numerous alternate universes that are essentially mirrors of our real world, often focusing on humans creating our own suffering because of our habitual weaknesses as humans. (p. 28)

In a century of war and terror, uncontrolled technological and scientific developments and use of the atom bomb, after the Second World War, Vonnegut appeared as a pacifist against the increasing totalitarianism, with the opinion that art is in charge of social critique. Vonnegut shows the degradation of human dignity and the cost of mechanization in his first novel, Player Piano. Although the novel owes many of its plot points to Orwell's 1984 and Zamiatin's We, Vonnegut wrote Player Piano when he was working at General Electric, which gave him enough ideas to consider the destructive effects of technology and machines on humanity. (Note 9) On 5 September 1965, Vonnegut, in an article published in the New York Times, stated:

Years ago I was working in Schenectady for General Electric, completely surrounded by machines, so I wrote a novel about people and machines, and machines frequently got the best of it, as machines will. (New York Times)

Player Piano is rooted in his job experience at GE. In a 1973 interview published in Playboy Magazine, he reveals his motivation for writing the fiction:

I was working for General Electric at the time, right after World War II, and I saw a milling machine for cutting the rotors on jet engines, gas turbines. This was a very expensive thing for a machinist to do, to cut what is essentially one of those Brancusi forms. So they had a computer-operated milling machine built to cut the blades, and I was fascinated by that. This was in 1949 and the guys who were working on it were foreseeing all sorts of machines being run by little boxes and punched cards. Player Piano was my response to the implications of having everything run by little boxes. The idea of doing that, you know, 
made sense, perfect sense. To have a little clicking box make all the decisions wasn't a vicious thing to do. But it was too bad for the human beings who got their dignity from their jobs. (p. 229)"

Vonnegut's time spent working at G.E. was unlike his criticism in Player Piano. Todd Davis (2001) discusses how Vonnegut, who was in charge of expanding the industrial way of life, glorifying industrial growth and inspiring consumerism at G.E., finally condemned all of them in his first fiction. Davis also states:

Vonnegut was intimately involved in the continued efforts by industry to communicate this idea of progress and expansion to the public during his tenure at General Electric. As a public relations writer, he was paid to find new ways of convincing the masses that the work done by industrial corporations was ultimately a step toward a brighter future, toward a vital and universal good that would benefit everyone in remarkable and miraculous ways. (p. 152)

In a 1993 interview, Vonnegut asks, "What if all economically useful work could be done more cheaply and satisfactorily by machines than by human beings?" (Reed \& Leeds p. 36). Vonnegut believes that the mechanization of society ruins human dignity. The concern that human roles are more and more played by machines is the basic theme of Vonnegut's Player Piano.

Furthermore, Player Piano condemns the American society of the 1950s. The satirizing tone that Vonnegut employs, the true nature of advertising that his novel discloses and the tedium that affects his characters despite possessing all the values of success and prosperity - these are the features of Player Piano that criticizes American consumer capitalism of the 1950s. As Howard Segal (1983) argues, the novel criticizes technology, mechanization, and human nature. According to Segal, Vonnegut depicts characters who "enjoy glass and steel houses whose amenities include microwave ovens, ultrasonic dishwashers and clothes washers and dryers, automatic ironers, and twenty-seven-inch colour television sets" (p. 164), all products promoted through the industry of advertising, as the tool of satisfaction and success. Furthermore, Segal states, "yet their living conditions do not compensate for their working conditions and thus do not eliminate their gnawing resentment and discount" (p. 164). Segal sees that life in Player Piano reflects life in the rest of Vonnegut's America,

The United States of Player Piano is, in a sense, itself a giant automated machine, with millions of parts. Not only is life for all citizens overwhelmingly automated, but every citizen has an assigned part in the social mechanism. (pp. 162-163)

Despite the discontent that pervades the lives of Vonnegut's characters, life in Player Piano is governed by efficiency, automation, the factory system, and consumerism which appear to equate with development and quality. Similarly, M. Keith Booker (1994b) states, Vonnegut

...recognizes that modern technology has made production so efficient that humans are more and more becoming necessary not as workers who produce goods, but merely as consumers who buy them. (p. 274)

He argues that Vonnegut's novel explores the motivations of his characters to continue purchasing consumer goods. But Booker fails to see that the people in Player Piano have no power to decide about their own life. I see that Vonnegut's characters become intelligent machines or consumer bodies that are unable to think and decide on their own lives. It is cybernetic system that manipulates their minds through inventing technologies such as the advertising system, information technology, and the computer that tell people what to do, to buy, to eat, etc.

Additionally, some scholars have seen a revolutionary function of the body in dystopian fiction. For instance, Olivia Anne Burgess (2010) argues about the significance of "the body as a means for renewed experience and dynamic change" in Payer Piano (p. 59). However, in our view, Burgess did not see the effects of consumer culture and the advertising industry that control the mind, in spite of giving freedom of action to the body. Burgess found the body to be a source of change, but he paid no attention to the mind control that occurred in the cybernetic environment of the 1950s.

Moreover, there is a vast body of criticism on Kurt Vonnegut's Slaughterhouse-Five. Critics have often glorified Vonnegut for Slaughterhouse-Five, which is greatly seen as the writer's masterpiece. The novel is not only a criticism of war, it has also been regarded as a criticism of America. As Robert Tally (2011) states,

The humane fatalism of Slaughterhouse-Five suggests one way of looking at the disjointed, often painful, experience of social life in the United States in the twentieth century. (p. 85)

Slaughterhouse-Five reflects Vonnegut's imprisonment by the Germans in Dresden during World War II. 
Observing the death of so many people and the destructive effects of war brought out his pacifist instinct. Two world wars and the Great Depression affected Vonnegut and caused him to experience a depressive period. Harold Bloom (2009) states that Slaughterhouse-Five is a "biographical context" that illustrates Vonnegut's experiences of the fire-bombing of Dresden. Moreover, Vees-Gulani (2003) explains that by Slaughterhouse-Five, Vonnegut considers the war anxieties. She notes that the fiction is

....an acknowledgment of the difficulty and inability to talk or write about a topic that deeply affected one's psychology ... Consequently one needs to design one's own coping strategies and path of healing to deal with the horror of the Dresden air raids. (p. 181)

The majority of the characters in the novel are either directly or indirectly harmed by an all-encompassing war that claims the lives of millions. Again, the theme of technology as damaging is present, and as many critics have noted, most of the technology in the novel is used for war or torture. But none of the critical works about the novel has considered the function of war as a mind-numbing machine that controls people and persuades them to participate in war and to kill each other by pressing a button.

Besides war, time is Vonnegut's other main concern in Slaughterhouse-Five. He shows the protagonist of his novel entrapped by Tralfamadorian time, which is not a traditional linear concept of time. Klinkowitz (1990) observes that the Tralfamadorian idea of time involves "the overthrow of nearly every Aristotelian convention that has contributed to the novel's form in English over the past three centuries" (p. 30). Furthermore, as Todd Davis (2001) writes,

...if time is thus viewed as a system of linear progression, meaning can be assigned to it, and, more importantly, tragedy (like the massacre in Dresden) can be explained as a logical step in the process. Vonnegut staunchly rejects this notion, and in doing so rejects perhaps the most totalizing myth in Western civilization - the myth that time is chronologically structured (p. 158).

Through this non-linear time Vonnegut makes the protagonist of his novel able to travel through time and narrate the story of Dresden. Moreover, interestingly, James Lundquist (1976) sees that, "The novel functions to reveal new viewpoints in somewhat the same way that the theory of relativity broke through the concepts of absolute space and time" (p. 69). Vonnegut attempts to create a union of all space and of all time.

From another perspective, David Goldsmith (1972) sees Vonnegut's observation of time as a way for the protagonist of the novel to escape from his horrible memories of war. As Goldsmith states, "Such a perspective simply provides the comforts which have enabled Vonnegut to live with his wartime nightmare" (p. 26). For Tralfamadorians, death is not important. Therefore, Goldsmith claims Vonnegut could finally wash the guilt and horror of Dresden from his mind. According to Goldsmith, non-linear time has a liberating nature, but Goldsmith does not consider that such an understanding of time is itself a form of imprisonment that controls the human mind.

In general, Vonnegut's works usually concern such themes as the marginalization brought about by technology. In this study, we are more in line with Thomas L. Wymer (1982) who, in "Machines and the Meaning of Human in the Novels of Kurt Vonnegut, Jr.", claims that "man himself is or may become a machine" (p. 41) is a regular theme in Vonnegut's fiction. This thematic concern is like the problem of human turning into slaves because they compete with machines that perform like slaves.

\subsection{Don DeLillo's Realistic Dystopian Fiction}

Don DeLillo (1936b) is known as one of the most adored authors of the twenty-first century. Harold Bloom (2003) regards Don DeLillo, Cormac McCarthy, Thomas Pynchon and Philip Roth the most influential contemporary American writers. Among these four writers, DeLillo is the most widely disputed. McCarthy, Roth and Pynchon's literary traditions are easily traceable, as Roth writes in the tradition of Kafka, Tolstoy and Joyce; McCarthy is like Melville, Hemingway and Faulkner; and Pynchon follows in the tradition of satirists such as Twain and Hawthorne However, DeLillo writes in various styles, which at times are Kafkaesque, Hemingwayian and even Pynchonean, and his mode of writing does not fall into a particular form of literary tradition. (Note 10) Thus, this feature has dedicated a vast body of critical work to DeLillo's fiction. In The Cambridge Companion to Don DeLillo, John Duval (2008) argues that,

In an age in which advertising has largely abandoned words in favour of the image, DeLillo, who still works with that old-fashioned word-assemblage called the novel, has a rare gift for historicizing our present, a gift that empowers engaged readers to think historically themselves. (p. 2)" 
Duval observes that DeLillo considers the world from the mid-twentieth century onwards and traces events such as "the rise of Adolf Hitler's fascism, the assassination of President John F. Kennedy, and Cold War brinksmanship" (ibid.). In his fiction, DeLillo illustrates the formation of contemporary American identity along with social and cultural changes. Moreover, according to Duvall, through his fiction, DeLillo sees the media as social forces. He shows the difficulty of thinking historically when our thoughts are shaped by television. Duvall states that for DeLillo, "the effects of the media serve as a fundamental mutation in Americans' lived relationship to the world" (ibid.). He depicts characters like "Hitler and Elvis Presley," who become "absorbed in the celebrity-making apparatus of media culture" (ibid.).

Furthermore, Engles and Duvall (2006) consider White Noise as one of the most discussed pieces of fiction due to its accessibility and brilliant treatment of various issues in contemporary American culture. They claim that DeLillo's work concerns contemporary American society and depicts issues such as toxicity, mass media, terrorism, consumerism, conspiracy and paranoia. (Note 11)

DeLillo illustrates various aspects of American culture and environment in his fiction. Schlager and Lauer (2001) observe that Delillo often addresses the "paradoxes and contradictions of postmodern culture" (p. 247). Moreover, according to Samuel Coale (2005):

DeLillo foregrounds the spectacle of contemporary culture as embodied in the media, sports, terrorism, language, money, sex, and consumer capitalism. The background of his fiction hints at some kind of ultimate visionary mystery, buttressed by his characters' inchoate spiritual yearnings and longings, probably nourished by DeLillo's own Catholic past and schooling. The postmodern disconnection often occurs between foreground and background, between the presentation of the poststructuralist materiality of language and culture and the aura of metaphysical uncertainty that hovers within and behind or beyond it. (p. 90)

By rising interest from cultural studies, more attention was paid to issues such as the TV, advertising and pop culture illustrated in DeLillo's fiction, and concepts such as simulacra and discourse were applied to DeLillo's work. Jean Baudrillard (1994) discusses that reality has now been substituted by simulacra and the "real" is replaced by what he calls the "hyperreal" (p. 166). A couple of critical works have considered DeLillo's works from Buadrillard's perspective of simulation. However, for the first time, John Frow (1990) clarifies the link between White Noise and simulacra. He discusses the function of simulation that both perverts and preserves the American myth of authenticity and originality. Frow considers television to be one of the pivotal elements behind this replacement. He argues that television reduces everything to mere information. Furthermore, Leonard Wilcox (1991) discusses that the way of life that DeLillo represents is "similar to that depicted by Jean Baudrillard." Wilcox states: "the transformations of contemporary society that Baudrillard describes in his theoretical writing on information and media have also gripped the mind and shaped" DeLillo's work. (p. 346)

Beside DeLillo's cultural and social concern, another prevalent theme in his texts is the notion of death, as many critics have considered it from Baudrillard's idea of simulation. In one of the most recent studies, Jennifer Camille Johnson (2007) observes:

In White Noise, the idea of life beyond death as a cultural icon in the novel supports Baudrillard's assertion in Simulacra and Simulation that "[d]eath is never an absolute criterion, but in this case it is significant: the era of James Dean, Marilyn Monroe, and the Kennedys, of those who really died simply because they had a mythic dimension that implies death". (p. 19)

As we mentioned above, Buadrillard sees that in the postmodern condition, reality is replaced by simulation. He observes that even death itself becomes a simulation. Additionally, Richard Devetak (2009) and Michael Hardin (2002) aligned with Johnson's observation of death in DeLillo's fiction.

Some critics also have examined the relationship between technology, identity or subjectivity in DeLillo's fiction. As in one of the most recent studies, Randy Laist (2009) sees that more than any other contemporary American writer, DeLillo considers the ways that have formed contemporary American consciousness, with the incursion of information, technology, consumerism, and the military into our daily life. Laist observes that, in DeLillo's fiction, technological devices are not only tools in the characters' daily life, but mysterious apparatuses that reshape human identity. DeLillo also illustrates people who present the encounter of an individual with a technological environment. Laist claims that DeLillo takes us into the heart of this new culture, in which "technologies reconfigure the relationship between ego and environment, between nature and nurture, and between the soul and the world" (p. 4). 
Although previous studies on DeLillo's fiction have observed the effects of technology on the self, consciousness, and identity, they have left enough space to consider transformation of the body in cyberspace.

DeLillo's Cosmopolis, which has received less critical views, also illustrates technology in the capitalist society of America in the early twenty-first century. Adam Thurschwell (2007) observes that DeLillo's Cosmopolis is "an allegory of self-destruction by the technologized capitalist society and its subsequent comeuppance in the violence it engenders in those whom it pushes aside" (p. 280).

Furthermore, Aaron Chandler (2009) examines DeLillo's "satire on global capitalism's contradictory inclination towards both cosmopolitan worldliness and solipsism," as represented in Cosmopolis, in the light of ideas of Emmanuel Levinas and Martin Heidegger in relation to "otherness" and "economy" (p. 241).

\section{Conclusion}

Huxley, Vonnegut, and DeLillo show their significant contributions to the development of the dystopian genre through their fiction. The dystopian novels of Huxley, Vonnegut, and DeLillo continue to have much to say about the most fundamental questions surrounding the human condition. They employ the dystopian genre to make us aware of human dignity and criticize modern technologies that can lead to our degradation. For them, genetic engineering, war, consumer culture, an automated world, and hypereality are among the phenomena that have affected the human mind and body.

\section{References}

Aldridge, A. (1984). The Scientific World View in Dystopia (No. 3). UMI Research Press.

Attarian, J. (1996). Brave New World and the Flight from God (pp. 332-342). Modern Age.

Baker, R. S. (1990). Brave New World: History, Science and Dystopia. New York: Twayne.

Baker, R. S. (1995). The Nightmare of the Frankfurt School: The Marquis de Sade and the Problem of Modernity in Aldus Huxley's Dystopian Narrative. In B. Nugel (Ed.), No More Than Ever: Proceedings of the Aldous Huxley Century Symposium, Munster 1994 (pp. 245-260). Frankfurt am Main: Peter Lang.

Bedford, S. (1973). Aldous Huxley: A Biography: The Apparent Stability (Vol 1). London: Paladin.

Baudrillard, J. (1994). Simulacra and Simulation. Ann Arbor: University of Michigan Press.

Beauchamp, G. (1986). Technology in the Dystopian Novel. MFS Modern Fiction Studies, 32(1), 53-63. http://dx.doi.org/10.1353/mfs.0.1315

Birnbaum, M. (2006). Aldous Huxley: A Quest for Values. Transaction Publishers.

Bloom, H. (2011). Bloom 's Guides: Brave New World. Infobase Publishing.

Bloom, H. (2009). Kurt Vonnegut's Slaughterhouse-Five. Bloom's Literary Criticism. InfoBase Publishing.

Bloom, H. (2003). Introduction. In H. Bloom (Ed.), Bloom's Modern Critical Views: Don DeLillo. Philadelphia: Chelsea House

Booker, M. K. (1994a). The Dystopian Impulse in Modern Literature: Fiction as Social Criticism. Westport, Conn: Greenwood Press.

Booker, M. K. (1994b). Dystopian Literature: A Theory and Research Guide. Westport, Conn: Greenwood Press.

Burgess, O. A. (2010). Utopian Body: Alternative Experiences of Embodiment in 20th Century Utopian Literature. Texas A\&M University.

Chandler, A. (2009). An Unsettling, Alternative Self': Benno Levin, Emmanuel Levinas and Don DeLillo's Cosmopolis. Critique, 50(3), 241-260. http://dx.doi.org/10.3200/crit.50.3.241-260

Coale, S. (2005). Paradigms of Paranoia: The Culture of Conspiracy in Contemporary American Fiction. University Alabama Press.

Davis, T. (2001). Apocalyptic Grumbling: Postmodern Humanism in the Work of Kurt Vonnegut. In At Millennium's End: New Essays on the Work of Kurt Vonnegut (pp. 149-166).

Davis, T. (2006). Kurt Vonnegut's Crusade Or, How a Postmodern Harlequin Preached a New Kind of Humanism. State University of New York Press

DeLillo, D. (2011). White Noise. Pan Macmillan.

DeLillo, D. (2011). Cosmopolis. Macmillan.

Devetak, R. (2009). After the Event: Don DeLillo's White Noise and September 11 Narratives. Review of 
International Studies, 35, 795-815. http://dx.doi.org/10.1017/S0260210509990192

Duvall, J. (Ed.). (2008). The Cambridge Companion to Don Delillo. Cambridge UP. http://dx.doi.org/10.1017/ccol9780521870658

Engles, T., \& Duvall, J. N. (Eds.). (2006). Preface. Approaches to Teaching DeLillo's White Noise (pp. 1-5). New York, NY: Modern Language Association of America.

Firchow, P. (1984). The end of Utopia: A Study of Aldous Huxley's Brave New World. Lewsiburg Pennsylvania: Bucknell University Press.

Fitting, P. (2010). Utopia, Dystopia and Science Fiction. The Cambridge Companion to Utopian Literature, 135-154. http://dx.doi.org/10.1017/CCOL9780521886659.006

Frow, J. (1990). The Last Things Before the Last: Notes on White Noise. South Atlantic Quarterly, 89(2), 413-429.

Goldsmith, D. (1972). Fantasist of Fire and Ice. In Popular Writers Series (Pamphlet No. 2). Bowling Green, Ohio: Bowling Green University Popular Press.

Gottlieb, E. (2001). Dystopian Fiction East and West: Universe of Terror and Trial. McGill-Queen's Press-MQUP.

Green, J. (2005). Late Postmodernism: American Fiction at the Millennium. Palgrave Macmillan. http://dx.doi.org/10.1057/9781403980403

Hardin, M. (2002). Postmodernism's Desire for Simulated Death: Andy Warhol's Car Crashes, J. G.Ballard's Crash, and Don Delillo's White Noise. Lit: Literature Interpretation Theory, 13(1), 21-50. http://dx.doi.org/10.1080/10436920210418

Harvey, D. (2000). Spaces of Hope (Vol. 7). Edições Loyola.

Hillegas, M. R. (1967). The Future as Nightmare: H. G. Wells and the Anti-Utopians. London: Oxford University Press.

Huxley, A. (2007). Brave New World. London: Vintage.

Huxley, A. (2005). Ape and Essence. Vintage.

Huxley, A. (1969). Letters of Aldous Huxley. London: Chatto \& Windus.

Huxley, J. (Ed.). (1965). Aldous Huxley: 1894-1963: A Memorial Volume. New York: Harper \& Row.

Johnson, K. L. (2009). Darwin's Bulldog and Huxley's Ape. Twentieth Century Literature, Darwin and Literary Studies, 55(4), 572-596.

Johnson, J. C. (2007). Body Politics in Don delillo, Adrienne Rich, and Andy Warhol: A Study in Postmodern Culture. North Carolina State University.

Kass, L. (2000). Aldous Huxley, Brave New World (1932). First Things, 10(1), 51-52.

Kass, L. (2002). Life, liberty, and the Defense of Dignity: The challenge for Bioethics. Encounter books.

Klinkowitz, J. (1990). Slaughterhouse-five: Reforming the Novel and the World. Twayne Publishers.

Klinkowitz, J., \& Lawler D. (Ed.). (1977). Vonnegut in America: An Introduction to the Life and Work of Kurt Vonnegut. New York: Delacorte.

Laist, R. (2009). American Environments: Technology and Subjectivity in the Novels of Don DeLillo. University of Connecticut.

Lundquist, J. (1976). Kurt Vonnegut. New York: Ungar.

McDowell, F. (1982). E. M. Forster. Boston: Twayne Publishers.

Meckier, J. (1996). Critical Essays on Aldous Huxley. New York: G. K. Hall.

Morse, D. E. (1997). Thinking Intelligently about Science and Art: Kurt Vonnegut's 'Galapagos'and 'Bluebeard'. Extrapolation, 38(4), 292-303.

Moylan, T., \& Raffaella, B. (Ed.). (2003). Dark Horizons: Science Fiction and the Dystopian Imagination. Psychology Press.

Murray, N. (2003). Aldous Huxley: A Biography. Macmillan.

Pickrel, P. (1952). Outstanding Novels. The Yale Review, 20. 
Rabkin, E. S., Greenberg, M. H., \& Olander J. (1983). No Place Else:Explorations in Utopian and Dystopian Fiction. Carbondale: Southern Illinois UP.

Reed, P. J., \& Leeds, M. (Ed.). (1996). The Vonnegut Chronicles: Interviews and Essays. Westport, Connecticut: Greenwood Press.

Russell, B. (2005). The History of Western Philosophy. New York: Routledge.

Sandoval-Becerra, C. A. (1991). Poetic and Dystopic Visions of Technological Society: The Essays of Eduardo Caballero, Aldous Huxley, and Michel Serres. State University of New York.

Scholes, R. E., \& Rabkin, E. S. (1977). Science Fiction: History, Science, Vision. New York: Oxford University Press.

Segal, H. (1983). Vonnegut's Player Piano: An Ambiguous Technological Dystopia. In E. S. Rabkin, M. H. Greenberg, \& J. D. Olander (Eds.), No Place Else: Explorations in Utopian and Dystopian Fictions (pp. 162-181). Carbondale: Southern IL University Press.

Simmons, D. (Ed.). (2009). New Critical Essays on Kurt Vonnegut. Palgrave Macmillan. http://dx.doi.org/10.1057/9780230100817

Sisk, D. (1997). Transformations of Language in Modern Dystopias. Connecticut: Greenwood Press.

Spindler, M. (1995). Taking the Message Bank from the Medium. New Perspectives Quarterly, 12(2), 48.

Tally Jr, R. (2011). Kurt Vonnegut and the American Novel: a Postmodern Iconography. Continuum International Publishing Group.

Thurschwell, A. (2007). Writing and Terror: Don DeLillo on the Task of Literature After 9/11. Law and Literature, 19(2), 277-302. http://dx.doi.org/10.1525/lal.2007.19.2.277

Varsam, M. (2003). Concrete Dystopia: Slavery and Its Others. In R. Baccolini, \& T. Moylan (Eds.), Dark Horizons: Science Fiction and the Dystopian Imagination (pp. 203-224). New York: Routledge.

Vees-Gulani, S. (2003). Diagnosing Billy Pilgrim: A Psychiatric Approach to Kurt Vonnegut's Slaughterhouse-Five. Critique, 44(2), 175-185. http://dx.doi.org/10.1080/00111610309599944

Vieira, F. (2010). The concept of utopia. The Cambridge Companion to Utopian Literature, 3-27. http://dx.doi.org/10.1017/CCOL9780521886659.001

Vonnegut, K. (2006). Player Piano. New York: The Dial Press.

Vonnegut, K. (1975). Slaughterhouse-Five. Panther Books Ltd.

Vonnegut, K. (September 5, 1965). Speaking of Books: Science Fiction. New York Times.

Vonnegut, K.. (1973). Playboy Interview. Wampeters, Foma and Granfalloons, 237-285.

Walsh, C. (1962). From Utopia to Nightmare. New York and Evanston: Harper \& Row.

Walsh, C. (2007). Modern Utopian Fictions from HG Wells to Iris Murdoch. CUA Press.

Wilcox, L. (1991). Baudrillard, DeLillo's 'White Noise' and the End of Heroic Narrative. Contemporary Literature, 32(3), 346-365. http://dx.doi.org/10.2307/1208561

Wymer, T. (1982). Machines and the Meaning of Human in the Novels of Kurt Vonnegut, Jr. In T. P. Dunn, R. D. Erlich, \& B. W. Aldiss (Eds.), The Mechanical God: Machines in Science Fiction. Westport: Greenwood.

Notes.

Note 1. Utopian thought is rooted in Paradise, a term that has its origin in 'pairidaeza', that in Old Persian means an enclosure; and in Old Testament Hebrew, it is seen as 'parades', that simply means a garden enclosure, and in Greek as 'paradeisos', which is a luxurious park.

Note 2. Frederick P. W. McDowell (1982) observes The Machine Stops was written during Forster's highly creative period. He explains, "In any event, the years from 1905 to 1910 were wonderful years of creative release and achievement for Forster, years in which his very inability perhaps to express himself emotionally to the fullest and to achieve sexual fulfillment provided him with a means whereby he could distance himself from his materials and attain an objective expression of his powers as writer and analyst of human behavior" (p. 8)."

Note 3. Maria Varsam (2003) investigates the concept of slavery in three dystopian novels: Margaret Atwood's The Handmaid's Tale (1985), Octavia Butler's Kindred (1979) and Harriet Jacobs's Incidents in the Life of a 
Slave Girl (1861). Furthermore, Eric S. Rabkin, Martin H. Greenberg and Joseph D. Olander published No Place Else: Explorations in Utopian and Dystopian Fiction (1983), including a collection of essays on dystopian fiction such as We, Brave New World, 1984, Player Piano and Fahrenheit 451."Moreover, Alexandra Aldridge, in The Scientific World View in Dystopia, considers dystopian fiction including We, Brave New World and Well's fiction. Aldridge mainly investigates the relation between technology and dystopian fiction."

Note 4. Raffaella Baccolini and Tom Moylan (2003) confront hope and despair in utopia and dystopia. They refer to some utopian researchers: Jane Donawerth, Peter Fitting, Naomi Jacobs, Ruth Levitas, Lucy Sargisson, Darko Suvin Lyman Sargent Tower, and also some younger ones such as Ildney Cavalcanti and Maria Varsam." The anthology concerns many of the critical arguments on utopian studies. They represent the utopias even within dystopian territories. Their view emerges from the notion that, "To speak of Utopia is to engage in an ongoing dialogue about locating hope and positive prospects amidst the (dark) horizons of contemporary sociopolitical discourse." (p. 1)

Note 5. Huxley's fiction is regarded as a speculative novel or novel of ideas that are often difficult to assess. The focus of this type of novel is neither on the plot of the story nor on the analysis of the characters; rather it is on the way that the characters reveal their ideas. Huxley states that the novel is "a discussion and fictional illustration of different views of life", adding that the "mere business of telling a story interested [him] less and less" (Bedford 148). Jerome Meckier (1996) notes that the novel of ideas has a significant role in literature, because it is "one of the obligatory modern forms, perhaps the most efficient means of gauging the extent of philosophical confusion in an age of unprecedented relativity" (p. 7). According to Meckier, in many of his novels, Huxley "exposed the interrelated dilemmas of the modern age", giving "not just utterance but also flesh and blood to life's perennial counterpoints and the modern era's cacophony of competing theories, each character the exponent of an attitude toward life" (p. 2). Huxley is described by his brother, Julian, as "a prophet" who uses his "malicious wit" (Julian Huxley, 21, 23) and attempts to make individuals aware of their foolishness."

Note 6. Bloom believes that the idea of "prophecy" in Brave New World is quite simplistic. He sees that for Huxley the novel was a cautionary one, rather than a prophecy. Huxley considered the rapid scientific and technological changes and developments. He states his goal of writing Brave New Word thus:

[Technology could] iron [humans] into a kind of uniformity, if you were able to manipulate their genetic background ... if you had a government unscrupulous enough you could do these things without any doubt ... We are getting more and more into a position where these things can be achieved. And it's extremely important to realize this, and to take every possible precaution to see they shall not be achieved. This, I take it, was the message of the book - This is possible: for heaven's sake be careful about it. (qtd in Bloom's Guide, p. 13)

Note 7. Ape and Essence, written as a film script, then became the novel that describes Huxley's concern for the future of humanity, in that if we continue to misuse technological developments, the results will be destructive.

Note 8. Jerome Klinkowitz and Donald L. Lawler (1977) observe that Vonnegut uses science fiction as a way to face the reality of the world. As they declare, "science fiction in Vonnegut's hands enables us to distance ourselves from ourselves, to face problems we cannot otherwise face directly. To enable himself and his readers to cope with the slaughter of innocents" (p. 93). However, Donald Morse (1997) declares that Vonnegut's fiction is against the principles of science fiction that consider "a resounding no! to any such unearthly faith in populating future worlds" (p. 293).

Note 9. Paul Pickrel (1952) explains that Player Piano is "the best humorous book I have read in some time", but "not so mordant or so powerful as Brave New World or 1984" Similarly, Charles Lee in Saturday Review characterized Vonnegut's first work as "wanting in Orwellian depth, but ... macabrely playful" (Davis Vonnegut's Crusade, p. 41).

Note 10. DeLillo is a multidimensional author. Some critics consider DeLillo to be a postmodernist who calls for the death of the enlightenment-modernist project. For instance, Jeremy Green (2005) observes DeLillo as a "representative postmodern novelist for the end of the century" (4). Green also argues that, "DeLillo has been an exemplary figure for the generation of postmodernist writers who began to establish careers during the 1980s and 1990s" (p. 4). Phil Nel, on the other side, in Duval's The Cambridge Companion to Don DeLillo, sees DeLillo as more modernist than postmodernist, as he claims: "DeLillo seeks the epic in the mundane, embraces a modernist avant-garde, writes a tightly controlled prose, and densely layers his allusive novels, modernism may be at least as important as postmodernism for understanding DeLillo's achievement" (p. 13). Additionally, Harold Bloom (2003) asserts that, "Despite [DeLillo's] supposed Post-Modernism, he is a High Romantic Transcendentalist" (p. 2). DeLillo himself is also unwilling to categorize his work as modernism or 
postmodernism. In a 1998 interview, he states:

Post-modern seems to mean different things in ... different disciplines. In architecture and art it means one or two different things. In fiction it seems to mean another. When people say White Noise is post-modern, I don't really complain. I don't say it myself. But I don't see Underworld as post-modern. Maybe it's the last modernist gasp. I don't know. (qtd. in Duval The Cambridge, p. 13)

Note 11. The significance of DeLillo's novels was revealed after their publication, since they have the capacity to predict cultural and ecological phenomena. Some weeks after the publication of White Noise and its Airborne Toxic Event, a chemical spill in Bhopal, India happened and many readers read the book based on the event in India.

\section{Copyrights}

Copyright for this article is retained by the author(s), with first publication rights granted to the journal.

This is an open-access article distributed under the terms and conditions of the Creative Commons Attribution license (http://creativecommons.org/licenses/by/3.0/). 